\title{
Language comprehension strategies of German language speakers with receptive skills in Hungarian
}

\author{
ISABEL ZINS
}

\begin{abstract}
This article deals with language comprehension strategies of German language speakers with receptive skills in Hungarian. This study explores how they come to terms with understanding two short Hungarian texts. To achieve this goal, I chose an introspective method of thinking aloud to visualize internal processes and strategies of comprehension. The results show that contextual knowledge and general knowledge of the world are highly important when it comes to (text) comprehension. In addition, the pronunciation of words must be properly memorized for the participants to be able to recognize them. Furthermore, the so-called "lack of contrast" plays an important role in the results, meaning that the participants often find the words familiar but are not able to access their meanings.
\end{abstract}

Keywords: receptive multilingualism; comprehension strategies; written texts; introspection; thinking aloud protocols; Hungarian; German

\section{Introduction}

This research is about a specific form of multilingualism, receptive bilingualism. Receptively bilingual interaction can be defined as: 
"[---] a mode of multilingual communication in which interactants employ a language and/or a language variety different from their partner's and still understand each other without the help of any additional lingua franca. [---] By definition, lingua receptiva is the ensemble of those linguistic, mental, interactional as well as intercultural competencies which are creatively activated when interlocutors listen to linguistic actions in their 'passive' language or variety.' (Rehbein et al. 2012: 248-249)

Understanding in such settings can be based on either mutual intelligibility of the languages (in the case of closely related languages), or on learning the other language as a second or third language or as a heritage language. The former is often referred to as inherent receptive bilingualism and the latter acquired receptive bilingualism (see Sherkina-Lieber 2020: 415).

Receptive multilingualism has been approached from two different research traditions: from the point of view of the possibilities offered by the linguistic similarity of closely related languages, and as a specific language skill, characteristic to situations with "incomplete learning" of the other language, such as in migration contexts. In the context of migration, receptive bilingualism has often been perceived with negative connotations. The speakers are often described as not having productive control over a language (see Romaine 1989: 10) and are therefore called passive bilinguals (see Campbell \& Muntzel 1989: 185) or semilinguals (see Safont Jordá 2005: 27).

Lippert (2010: 47-48) describes receptive bilingual speakers, of a heritage language or second language, as being well-trained in receptive linguistic competencies, i.e. in listening and reading (reading mostly underdeveloped, however). As listening also entails an active competency of taking part in what is going on, instead of "passive competency", she rather chooses the term receptive, as it is also recommended by other researchers, such as Rehbein et al. (2012). Thus, receptive bilingualism enables conversation between people who do not necessarily speak the same language. Vetter (2011: 350) even emphasizes that "[---] it goes 
beyond minimal linguistic knowledge, incomplete language learning and so-called passive competence, as it requires multilingual communicative strategies which are usually not focused on in language learning." Especially listening skills and potentially reading skills are developed.

Several studies have already been conducted with receptive inherent or acquired bilinguals as the target group. Some of them focus on mutual intelligibility of closely related languages, as for example the Micrela project including 16 European languages of three language groups: Germanic, Romance and Slavic (see Heuven et al. 2015; Gooskens et al. 2018). Other researchers have been interested in receptive bilinguals of heritage or second languages, like Sherkina-Lieber, Pérez-Leroux and Johns (2011) who investigated grammar comprehension of Englishdominant non-fluent heritage speakers of Inuktitut. It is important not to mix up these research traditions because they approach the topic from different theoretical backgrounds and with different research interests.

The study presented in this paper focuses on German-Hungarian receptive bilinguals, with German as the dominant language and Hungarian as a heritage or second language. German and Hungarian are unrelated languages. In this article, I will discuss several strategies of language comprehension according to Lutjeharms (2002) and examine which of the described strategies are used by German-speaking people with receptive skills in Hungarian when reading two Hungarian texts.

\section{Communicative constellations of receptive bilingualism}

Receptive bilingualism can evolve through different contexts and situations, such as in cross-generational communication, in border regions, and in institutional discourses. Institutional discourses have been studied for example in educational settings and in workplace contexts. Migration is an important factor to consider when family members of the elder generation use an immigrant language, but the children respond in the majority language (Rehbein et al. 2012: 252-253). In this respect, 
Lippert (2010) who conducted qualitative interviews with eleven more or less bilingual families in Italy discusses the Three-Generations-Rule. According to the rule, the first generation of migrants is monolingual and acquires the language of the new home country well enough, but not entirely. The second generation is bilingual, and the third generation again monolingual in the language of the immigration country. In this model receptive bilingualism is an intermediate stage connected to migration and always leads to loss of language (Lippert 2010: 26-48).

Three participants of this study grew up exposed to a mixture of two to three languages, including Hungarian, and acquired receptive skills in Hungarian by listening to older family members. In this study, another language context connected to the family is added, namely the informal discourse of two women communicating with their Hungarian parentsin-law and gaining receptive skills in Hungarian. The time of exposure to the language is shorter than in the first described context.

Receptive bilingualism or multilingualism can also appear in border regions, as presented in this study with the example of Austria and Hungary. Although German seems to be very distant to Hungarian regarding the language typology, receptive multilingualism may still work because of socio-linguistic and historical reasons. Hungarian has been influenced by German since the 13th century. Public administration, education and even the press was dominated by the German language representing more prestige. At the beginning of the 19th century, the Hungarian language began to gain acceptance and slowly replaced German. Some language mixes of German and Hungarian arose (Hetzer 2009: 118). Two participants are considered to be receptive bilinguals because of the long-lasting language contact in this border region.

\section{Language comprehension strategies}

The present study analyses language comprehension strategies of receptive bilinguals of German and Hungarian. German and Hungarian are unrelated languages. Hungarian is a Uralic / Finno-Ugric language, 
whereas German is an Indo-European language of the West-Germanic branch. Hungarian and German are also typologically different. German represents an inflected language with four cases, three genders and a strict word order. German uses inflections to show grammatical functions (for more information see e.g. Duden 2009). It contrasts with Hungarian that is an agglutinative language, which simply put means that the grammatical functions are expressed by suffixes and postpositions, while the word order in a sentence remains fairly free. The differences between these two languages also concern the lexicon. Although there are lots of influences and loanwords effected through the history in both languages, there is neither a genetic nor a typological similarity that would lead to a common basic vocabulary or mutual intelligibility (for more information see e.g. Dengscherz 2005 or Forgács 2001). In conclusion, if a German speaker understands Hungarian, the understanding is based on acquired language skills.

Thus, the research subjects cannot by and large resort to the similarity of the languages while they try to understand texts in their weaker language. Walter Kintsch (1998:2) suggests that context is crucial for comprehension, which is also emphasized by Michail Bachtin in his explanations of the Theory of Dialogic Imagination. Bachtin states that meaning is only understood in context and environment (Deutsche Literatur: Dialogizität; Bachtin 2015: 199-212). According to Kintsch, the other components of comprehension are linguistic rules and strategies. He defines rules as a kind of algorithms that always lead to the exact right solutions. Strategies on the other hand will not always lead to the right solutions, and if they do not, they are replaced by other strategies. (Kintsch 1982: 268-269) Therefore, strategies represent a variable depending on the context.

The main interest of this study lies within the learners' strategies as they present linguistic competencies of the participants. These are conscious acts trying to solve the (linguistic) problem on one's own, using linguistic units and simplifying structures or knowledge of the world (see Lutjeharms 2002: 126). For that, Lutjeharms proposes the category of "Untere Verarbeitungsebenen", here called "lower procession 
levels". According to Lutjeharms (2002: 127-133), there are four levels of language processing: The graphophonic level is about the connection between the written letters and the right pronunciation. Word recognition identifies words and classifies them in the mental dictionary. The syntactic level analyses the sentence structure and the connection between the words. The semantic level summarizes singular pieces of information into a global understanding.

\section{Data and method}

Based on the presented target group of German-speaking people with receptive skills in Hungarian, the study on hand aims to answer the following questions concerning language comprehension strategies:

- Which language comprehension strategies in Hungarian are used by receptive bilinguals with German as their dominant language, when reading a factual text and an epic short text?

- Which so-called "procession levels" (according to Lutjeharms 2002) are activated by the receptive bilinguals when generating (text) comprehension?

The method of this research is thinking aloud, which is an introspective method used in language acquisition studies. In a think aloud study the participants are requested to express their thoughts aloud while doing a certain activity to show internal and cognitive processes (Heine 2014: 124). Jessner (2006:140-141) has used think-aloud protocols to examine the process of academic writing of multilinguals. Her results show the importance of establishing and strengthening metalinguistic and metacognitive abilities in the language learning and giving up on working on isolated items.

The participants of this study are German speakers with low active skills in Hungarian. According to the Common European Framework of Reference for Languages (CEFR) their language levels range between $\mathrm{A} 0+$ to $\mathrm{A} 2$, and they have acquired their knowledge "naturally". To maintain anonymity, the participants' names are replaced by nicknames. 
In 2017/18, when this study was conducted, the eight participants' age range was 19 to 37 years.

Gerhard (G) and Adam (A) both live close to the Hungarian border and therefore hear a lot of Hungarian. They have never learned the language formally but understand it quite a bit. Caro (C) and Julia (J) both have Hungarian boyfriends whose parents only speak Hungarian. In that way, they are confronted with Hungarian quite often. They have never actually learned the language, or at least not a lot of the learning process was actively, consciously done. They learn by listening. Daniel's (D) and Lilla's (L) mothers both grew up in bilingual Hungarian-German settings. The mothers have lived in Austria since their births or childhoods and have Austrian husbands. They did not speak much Hungarian with Daniel or Lilla, who both understand small talk in Hungarian but cannot speak it. Stefan (S) grew up with a mixture of Romanian, German and Hungarian. Hungarian was used only for communicating with his mother, while the rest of the communication was done in the other languages. Romi (R) grew up in Hungary until the age of seven but has not used the language since then.

The participants were given two Hungarian texts (see below), one journalistic text on a current topic and one epic text, the beginning of a modern fairy tale. They were requested to read the texts and to express their thoughts aloud on how they try to come to an understanding of the text without using external help (see Riemer 2014: 21-22). The objective was to make their thoughts visible, in order to study the strategies used by the participants to understand the texts.

Both texts are from a weekly published Hungarian women's journal providing information on current topics in simple language. The first text is about a mobile game called "Pokémon Go". By choosing this text, I aimed to stimulate different strategies like knowledge of the world or semantic knowledge. The second one is the beginning of a modern fairy tale. Here, I aimed at activating concrete linguistic knowledge like word order or morphology. The different structures of these texts were supposed to elicit various language comprehension strategies. 
TeXt 1.

Pokémon Go

A zsebszörnyek (Pocket Monsters) újra divatba jöttek! A Nintendo kézi játékkonzolaira tervezett figurákkal húsz évvel ezelőtt csak a virtuális valóságban játszottak a fiatalok, majd képregényekben és rajzfilmeken lehetett velük találkozni, három hete azonban mindenki rájuk vadászik a parkokban, utcákban, a szomszéd kertjében. A Pokémon Go okostelefonos alkalmazás lényege, hogy a játékos minél több rejtőzködő figurát begyüjtsön. Egy hét alatt hódította meg az egész világot a játék. [Pokémon Go

The pocket monsters have come into fashion again. Twenty years ago, teens only played in the virtual reality, using characters developed for Nintendo's game console. Soon you could meet them in comic strips and cartoons. For three weeks, however, they have now been hunted in parks, streets, and neighbours' gardens. In essence, the Pokémon Go Smartphone game is about collecting as many hidden characters as possible. Within a week, the game conquered the world.]

\section{TeXt 2.}

Az utolsó béka

Volt egyszer egy gólya, teljesen egyedül lakott a falujában. Nem volt se felesége, se öccse, se bátyja, se apja, anyja. A házát is egyedül építette. Békákra vadászott. Ebből élt. Megette mind a tó békáit. Csak egyetlenegy szem béka maradt. Egy este, már sötétedett, amikor a gólya hazaért a békavadászat után. Amielőtt a béka kopogott az ajtón, a gólya a tüz után nézett...

[The Last Frog

Once upon a time there was a stork who lived alone in his village. $\mathrm{He}$ had neither wife nor little brother, nor older brother, nor father, nor mother. He had also built his house alone. He hunted frogs. That was what he survived on. He ate all the frogs in the lake until only one frog was left. One evening the stork returned late because he had hunted until dusk. Before the frog knocked on the stork's door, the stork had tended to the fire...] 
The verbal data were recorded with the Audacity program and transcribed using the F4 application. The transcriptions were encoded using the MAXQDA program. For getting the participants used to the unusual situation of vocalising their thoughts, I gave a test run beforehand using a Portuguese text. Portuguese was chosen because it is a language hardly learned in Austria, while deduction is partly possible because of internationalisms and similarities with other Romance languages.

The data were analysed according to the principles of Mayring's Qualitative Content Analysis (in short QCA). The QCA represents an empirical method for the systemic description of the content or the form of verbal data. It is an appropriate method for theory-oriented research questions (see Mayring, Brunner 2013: 324-326; Früh 2015: 29), as given in this study. The method used is a combination of deductive and inductive procedures (see Kuckartz 2016: 95), as the designed categories have partly been determined beforehand, but partly been developed during the analysis.

\section{Results}

For the interpretation of this data, the following theory-based criteria, as outlined in the table 1 below, are used. In this article, only the major findings about learners' strategies and the so-called "lower procession levels" as subcategories of the learners' strategies are presented. Other subcategories evolving in the course of evaluation are named with the results below. 


\begin{tabular}{|c|c|c|}
\hline Category & Examples & Explanation \\
\hline $\begin{array}{l}\text { Learners' } \\
\text { strategies }\end{array}$ & $\begin{array}{l}\text { e.g. repeating, accessing } \\
\text { information, imitating, } \\
\text { recirculating, recognizing, } \\
\text { classifying, organising linguistic } \\
\text { units, simplifying structures, } \\
\text { translating consciously, applying } \\
\text { rules consciously, evaluating } \\
\text { one’s own learning process, } \\
\text { revision, knowledge of the world }\end{array}$ & $\begin{array}{l}\text { conscious acts trying to } \\
\text { solve the problem on one's } \\
\text { own }\end{array}$ \\
\hline $\begin{array}{l}\text { Graphophonic } \\
\text { level }\end{array}$ & $\begin{array}{l}\text { e.g. reading the words in the } \\
\text { right way or not }\end{array}$ & $\begin{array}{l}\text { connecting written letters } \\
\text { to their pronunciation }\end{array}$ \\
\hline $\begin{array}{l}\text { Word } \\
\text { recognition }\end{array}$ & e.g. transfer, false friends & $\begin{array}{l}\text { the mental dictionary } \\
\text { accessing single words or } \\
\text { the right translation }\end{array}$ \\
\hline Syntactic level & $\begin{array}{l}\text { e.g. word order, sentence struc- } \\
\text { ture, morphology, congruency, } \\
\text { animacy, inanimacy, valency }\end{array}$ & $\begin{array}{l}\text { considerations and transla- } \\
\text { tions aimed at word order } \\
\text { in the sentence, sentence } \\
\text { structure }\end{array}$ \\
\hline Semantic level & $\begin{array}{l}\text { e.g. summarizing singular pieces } \\
\text { of information }\end{array}$ & $\begin{array}{l}\text { condensation of singular } \\
\text { pieces of information into } \\
\text { global understanding }\end{array}$ \\
\hline
\end{tabular}

\subsection{Learners' strategies}

The main interest of this research lies within the learner's strategy, i.e. conscious approaches to globalisation, avoidance, interpretation of signs or even deduction of rules, etc. (see Lutjeharms 2002: 126-127; Scherfer 2002: 95; O’Malley \& Chamot 1995: 46, 49-52; Friederici 1987: 52). A sighting of the material especially shows the conscious application of strategies that are formed on the meta-level.

Five of the eight participants explicitly describe their approaches. In example (1) the participant explicitly says that she does not really understand the sentence but deduces the general context from the words she knows. 
(1) C [hun/ger]

majd képregényekben és rajzfilmeken lehetett velük találkozni (ähm) (..) also Zeichentrickfilme und (lachend) es war etwas möglich... ich kann mir das nur so herleiten von den Wörtern, die ich schon kenne... es war nur möglich die von Zeichentrickfilmen her zu kennen oder zu treffen...

[Soon you could meet them in comic strips and cartoons. (um) (..) means cartoons and (laughing) something was possible... I can only deduce the meaning from the words I already know... you can only know that or see that in cartoons...]

In example (2) the participant tries to deduce the meaning from another language she knows, but she's beware of the fact that the strategy is not working.

(2) $\mathrm{R}$ [hun/ger]

Nein! Egy... egy heißt immer eins... oder ein... (..) aber (6s) also ich kann da jetzt auch keine andere Verbindung machen mit irgendeiner anderen Sprache (lachend) kommt mir vor, also (..) nein.

[No! A... a always means one... or a/an... (..) but (6sec) I can't even make a connection with another language (laughing) I suppose, so (..) no.]

At other times, Romi tries to find a way via other languages but sees the difficulty of doing so, as there are no close relations between Hungarian and other languages. These examples show that the participants consciously use strategies to solve the problem of understanding the text, referred to as learners' strategies.

Repeatedly, I will point out that the participants' knowledge of the world as part of the learner's strategy is probably crucial for some deductions and interpretation approaches, meaning the receptive bilinguals have prior knowledge of a topic and are thus able to fill in the blanks using their knowledge of the world, as in example (3).

(3) $\mathrm{R}$ [hun/ger]

R: Ja! Kézi... játékkonzolaira. Also (.) konzolaira wäre die Konsole wahrscheinlich, das heißt (.) auf einer Nintendo Konsole (...) spielt 
man (..) mit Figuren (lachend) (ähm) virtuell (..) valóságban (..) játszo... fiá...(.) fiá... (.) fiá...

I: Fiatalok. Wo hast du „Spielen“ übersetzt?

R: Ich hab das dazu erfunden. Also... weil... aber... auch nur weil ich weiß, dass es... was Pokémon Go ist. (..) also, ich versteh nämlich nur: Nintendo, Konsolen, mit (..) Figuren, in einem bestimmten... ich nehme an.. irgendein Fall wird das sein. (ähm) (..) virtuelle w... válóság...

[R: Yes! Hand... game consoles. So (.) consoles would probably be a console, that means (.) on a Nintendo console (..) you play (..) with characters (laughing) (um) virtually (..) in the world (..) play... teens... (.) te... (.) te...

I: Teens. Where did you translate "play"?

R: I added it. Just... because... but... but just because I know that... what Pokémon Go is. (..) Well, I only understand: Nintendo, consoles, with (..) characters, a certain... I suppose... it must be something like that. (um) (..) virtual w... world...]

Romi recognizes the words for game console and characters. Therefore, from her knowledge of the world, she concludes that this must be played. When asked where she got the word from, she says she just added it herself because she knows about Pokémon Go. Thus, her knowledge that people play on a console, leads her to the right translation, as the text in fact says játszottak 'they played'.

Gerhard has little to hold onto in the Pokémon text. At the end, he gives a sort of a summary of the text and adds several pieces of information that he concludes from his knowledge of the world, in this case about Pokémon Go:

(4) G [hun/ger]

Ich könnte mir vorstellen, dass es da darum geht, dass es (ähm) um das Spiel (.) Pokémon (.) Monster (.) geht. Dass es (ähm) irgendeine... eine neue... eine neue Möglichkeit ist (.), dass das gespielt wird, oder (ähm) irgendwie angesehen wird, auch irgendwie... im... im Leben, weil halt irgendwie von den... von den Park... von Park und Straße und so irgendwie die... die Rede ist. Und dass das irgendwie (.) beschreibt, 
dass die Jugend sich irgendwie damit befasst, würde ich jetzt glauben.

[I think that this is about, that it (um) is about the game (.) Pokémon (.) monsters (.). That it is (um) some... a new... new possibility (.), that it is played or (um) somehow is looked at and somehow... in... in everyday life, because it somehow...deals with the... the park... the park and the street and so on. And that that somehow (.) describes that teens do something, I believe.]

In example (4), Gerhard works on the basis of the words he translated: pocket monsters, new, park, street. Using his knowledge of the world, he can then add the words "play" and "game" as well as "the teenagers" to his translation, without being aware that the text really contains them.

\subsection{Graphophonic level}

One of the challenges in understanding for the participants was the fact that they did not really have reading competency in Hungarian. As the target group was set to consist of people with a low level of Hungarian language proficiency who have, in addition, not been taught the language, the cultural technique of reading in Hungarian had not been strengthened or even rehearsed. If the graphophonic level does not trigger recognition, accessing the meaning becomes difficult.

The difficulty with reading is illustrated in example (5) in which the participant describes understanding being easier after hearing the text read aloud. Daniel, who grew up hearing some Hungarian, asked the researcher to read the text aloud after failing to understand the written text. That can be described as his problem-solving strategy.

(5) $\mathrm{D}[$ hun/ger]

D: Jetzt ist es besser! (lachend)

I: Ist dir vielleicht jetzt, weil ich das vorgelesen habe, noch irgendetwas eingefallen oder möchtest du noch etwas sagen zum ersten Text? 
D: Also, der erste Satz... (lachend) der erste Satz heißt... (ähm) dass das Pokémon Spiel jetzt... also, es ist jetzt etwas Neues herausgekommen. (ähm)

[D: Much better now! (laughing)

I: Anything you want to add now that I have read it or anything you want to say about the first text?

D: Yes, the first sentence... (laughs) means... (um) the Pokémon game now... so there was a new release. (um)]

As example (5) shows, Daniel thinks he understands more after hearing the text, and he indeed recognizes the word $u j$ as 'new' and possibly also jöttek as 'they came.' Another participant attempts to find the right pronunciation on his own, trying to link sounds to the letters of a word. Thus, accessing the words in the participant's memory is closely connected to the right pronunciation. So, the graphophonic level plays an important role in word recognition, which will also be elaborated on below.

\subsection{Word recognition}

There is a difference between words (correctly) accessed in the mental dictionary and deduced meaning. The following subcategories of "Word recognition" emerged and will be further explored below: accessing the word in the mental dictionary and transfer.

\subsubsection{Accessing the word in the mental dictionary}

In this study, general problems in accessing the word in the mental dictionary appeared when some words triggered a recognition process, but the participants could not identify the meaning of the word in their mental dictionary. For example, two participants say the word is familiar, but they cannot seem to find the exact meaning. 
(6) L [hun/ger]

(4s) Ja und manche Wörter kann... also (..) kenne ich eben, aber kann sie nicht (..) übersetzen, aber sie sind mir (...) eben bekannt. $[(4 s)$ Yes and some words... that is (..) I just know them, but can't (..) translate, but they are (...) just familiar.]

(7) R [hun/ger]

(.) a film... rajzfilm... lehetett velük találkozni... találkozni! Das kommt mir bekannt vor, aber ich weiß es nicht. (4s) [(.) a film... cartoon... could meet them... to meet! This sounds familiar, but no idea $(4 \mathrm{sec})]$

Lilla und Romi hear familiar words but cannot access them in their mental dictionaries. This phenomenon could be due to a so-called "lack of contrast", according to Lutjeharms (2002: 130-131). The "lack of contrast" describes a phenomenon that triggers recognition on the morphologic level because of the clear similarity to other words of the target language, but the words are not analysed or the speakers do not ask for their meaning. The words are clearly recognized as typical Hungarian but not connected to a specific meaning. They rest "unanalysed" and therefore the participants in this study know that they have already heard these words but they have no connection to a specific meaning.

The following examples show that the participants recognize some words only within a general category, but the exact meaning is not always clear. For example, it might be clear that the word meaning is some animal or relative, but the participant cannot say what animal or relative exactly.

(8) D [hun/ger]

und es war einmal ein... ein... egy gólya, das dürfte heißen irgendein... aus... ein Tier eben.

[and once upon a time there was a... a... a stork, that should mean some... from... some sort of animal.]

In example (8), Daniel describes that he knows the word gólya 'stork' to mean some kind of an animal, but not what it exactly is. Stefan 
(example 9), too, is not sure about the kind of animal this could be in the beginning, but later guesses correctly that it might be a stork.

(9) S [hun/ger]

Volt egyszer egy gólya boah, ich weiß gólya ist ein Tier, aber ich weiß es gerade nicht, welches Tier. Also, es war einmal ein (...) Ah! Gólya ist ein Storch. (...) Ah! Genau! Glaube ich. Ja, schauen wir mal.

[Once upon a time there was a stork... O my, I know stork is an animal, but I don't know which one. So once upon a time there was a (...) Ah! Stork is a stork. (...) Ah! Yes! I think so. We'll see.]

Before this, Stefan already has translated the animal in title correctly: $A z$ utolsó béka as 'The last frog. Based on that, he may just conclude that the next protagonist must be an animal too. Daniel, in contrast, fails in translating the title, but still puts gólya as 'stork' into the "animal-section". He recognizes the type of the text, namely a fairy tale, because of the phrase at the beginning. He clearly knows that it has to be some sort of an animate figure who is playing the main role. This can only be a person or an animal. At the moment and concentrating on single words, he opts for an animal.

Similarly, family is a semantic category that helps the participants to infer a meaning of a word they do not know. In the fairy tale text, some participants recognize the basic vocabulary, like mother and father, and based on that guess the unknown word to mean some kind of a relative.

(10) G [hun/ger]

(...) anyja weiß ich, ist die Mutter. (...) (ähm) und und und batyja ist, glaube ich, die Großmutter, soweit ich weiß. (..) also das sind irgendwelche, nehme ich mal an, irgendwelche

Aufzählungen von Verwandtschaftsgraden (..) vermutlich. (...) [(...) his mother I know that's the mother. (...). (um) and and and older brother I think means grandmother, as far as I know. (..) I guess this is some enumeration of family members (..) I think. (...)]

In example (10), Gerhard rightly identifies anyja as 'his mother' but wrongly translates bátyja as 'grandmother', rather than as 'his older 
brother', and then says that this must be an enumeration of relatives. So, he correctly recognizes the general category but not the word itself.

One can say that the first words function as primes (see Hoey 2005) that activate the frame of relatives or animals, as well as their usual collocates (see Muikku-Werner \& Jantunen 2020). Importantly, the prime and the target are placed in close proximity: The words are mentioned within one sentence or in the following sentences and so the participants assume a relation. The participants know that the topic of the text won't change immediately.

\subsubsection{Transfer}

The participants were very successful in deducing words from other languages or internationalisms where possible. Even the participants who believed not to understand anything, could at least hold on to these words:

(11) S [hun/ger]

A konzolaira würde ich sagen ist die Konsole, würde ich mal sagen.

[For the console I would say this is a console.]

(12) R [hun/ger]

Ja, ich verstehe (.) nichts. Also irgendwas... eine, eine virtuelle... von virtuálisz... würd ich sagen, ein virtuelles (..) váloságban. (ähm)

[Yes, I don't (.) understand. So some... a virtual... from virtual... I'd say a virtual (..) in the world. (um)]

As examples (11) and (12) show, even when understanding beyond internationalisms was hardly possible, at least those words were identified and reproduced accurately. That way, the fairy tale text was thought to be more difficult by some participants, intentionally without internationalisms. 


\subsection{Syntactic level}

The syntactic level concerns sentence structure, and it includes several subcategories, e.g. valency and word order. The syntactic level phenomena show how the participants understand linguistic structures that go beyond the recognition of single words.

The category of word order is explicitly focused on here because of the substantial differences between Hungarian and German word order. German represents a typical SVO language with a strict word order showing grammatical relations, generally spoken, with inflections of articles and nouns (for more information see e.g. Duden 2009). Hungarian has got a very free word order and is considered to be SOV language, which means that the verb is most often placed at the very end. Frequently the subject is missing because the verb also points out the information about the subject. The first noun is rarely the subject in the nominative case and can be an object or other constituent marked by suffixes (for more information see e.g. Forgács 2001).

The participants in this study recognize simple structures of word order in a sentence, especially when the word order is close to the German grammar, as the following example (13) illustrates:

(13) C [hun/ger]

Megette mind a tó békáit... Er hat vom ganzen See die... die Frösche aufgefressen.

[He ate all the frogs in the lake... He had from the whole lake... eaten the frogs.]

Caro begins at the top of the sentence megette as 'he ate' which is the verb including the information about the subject. The object is following as it is common in German grammar, and she succeeds in translating the phrase correctly.

Still, complex or non-linear sentences pose a challenge to the participants. Example (14) illustrates the interference between the German and the Hungarian word orders and shows a transfer phenomenon. 
(14) J [hun/ger]

A házát is egyedül épitette... Das Haus ist auch ein leeres Gebäude... leer oder ein (.) alleinstehendes Gebäude.

[He had also built his house alone... The house is also an empty building... empty or a (.) stand-alone building.]

A házát is egyedül épitette translates as 'he also built his house alone', and it contains the subject-related information in its last word. Épitette translates as 'he built', and the first noun házát 'his house' is in the accusative case. This confuses Julia who bases her translation on German word order. She expects the first noun in the sentence to be the subject and translates it to German by using the nominative case. Furthermore, she interprets the last word épitette as 'he built as a noun for building, which would be épület.

Thus, she uses her German native language grammar knowledge to translate the Hungarian sentence. She translates the adverb egyedül 'alone' as an adjective, 'empty', which makes sense in the context, as it precedes the word that she assumes to mean 'building. In German, as well as in Hungarian, the adjective is normally placed before the noun, and so she translates the phrase as adjective with a noun instead of adverb with verb. In example (15) Julia explains right after, how she deals with the Hungarian word order:

(15) J [hun/ger]

...für mich ist die Satzstellung gerade etwas... weil's eben nicht wie im Deutschen ist, sondern man muss sich teilweise die Wörter so ein bisschen zusammenstellen (..) und deswegen muss man dann wieder auf Intuition achten, was sich für einen gut anhören würde (..) genau... [...for me word order is a little... because it's not like in German, you have to put the words together on your own a little bit (..) and so you have to make an intuitive decision, what would sound right for you (..) yes...]

In example (15), she emphasizes that she knows that Hungarian word order is different from German and that she relies on her intuition. Similarly, in Romi's translation in example (16), there's a transfer from the 
German word order. Julia and Romi both start at the beginning of the phrase with the noun in the nominative case, as it is common in German, and translate every following word one after another:

(16) $\mathrm{R}$ [hun/ger]

Amikor a gólya... a békavadász után (4s) irgendwas mit... der Storch macht irgendwas mit dem Frosch. (lachend) also, amikor a béka hazaért a békavadás után. Da macht der Storch glaub ich irgendwas mit dem Frosch, aber auch nur weil... (..) der Storch steht zuerst und $a . .$. (..) be... irgendwas mit Storch... irgendwas mit dem Frosch seinem irgendwas... macht er, hätt' ich jetzt gesagt.

[As the stork... after the frog hunting (4s) something about... the stork does something to the frog (laughs) well, as the frog returned after the frog hunting. I think that means the stork does something to the frog, but just because... (..) stork comes first and the... (..) fr... something about the stork... something about the frog's something... that's it, I'd say.]

As example (16) shows, Romi cannot exactly say what happens in the story, but she thinks the stork does something to the frog. However, this interpretation is based on the assumption that the subject starts a sentence, and the object follows later.

\subsection{Semantic level}

The semantic level refers here to the connections the participants make beyond word and syntactic levels, as they for example summarize longer and larger passages of the text (see Lutjeharms 2002: 129-132; Gold 2007: 19-20). The participants try to understand the general meaning of the text and not to hold on to single words or certain sentences, especially if they are more experienced and have enough linguistic material to draw on.

In example (17), Daniel summarizes the fairy tale, not focusing on the word order or single words he doesn't know. He creates a story line about a protagonist, his circumstances, a problem, another protagonist and the beginning of the meeting of these figures. 
(17) $\mathrm{D}$ [hun/ger]

Also, pass auf. A béka ist eine Ziege (..) utolsó heißt, das Letzte (.) und der gólya ist ein Riese und das ist eine Geschichte von einem Riesen (.), der hat (ähm) der hat in der Nähe von irgendwo gewohnt und der hat nichts gehabt und der hat (..) der hat dann alle aufgegessen, alle Ziegen (.) und nur eines ist übrig geblieben und wie der (.) wie dann irgendeines Abends (.) (ähm) es war schon in der Dämmerung (.) (ähm) hat der (ähm) hat der (ähm) amikor a házát is... után... der war schon in der Nähe vom Haus... da hat er die... die... die letzte Ziege (ähm) die... die (ähm) die... die Tür irgendwie aufgemacht und... und... hat durchgeschaut. (lachend) es ist eine sehr schöne Geschichte.

[Listen. The frog means goat (..) last means the last (.) and stork is a giant and the story is about a giant (.), who has (um) who lived near some place and had nothing and he has (..) he ate all, all goats (.) and only one was left and as (.) one evening (.) (um) dusk had set in (.) (um) he has (um) he has (um) as his house... then... he was already near the house... there he has the... the... the last goat (um) the... the (um) the... the door opened and... and... and looked through (laughs) it is a nice story.]

Interestingly, Daniel cannot interpret the two protagonists correctly. He translates béka 'frog' as goat and gólya 'stork' as giant. In general, he creates some translation help by assigning names to the two words coming up throughout the story. However, Daniel recognizes the size relation between the protagonists: as béka 'frog' gets translated as a 'goat', respectively the other protagonist has to be a bigger creature, 'giant' in his translation. For understanding the storyline, it is not very important whether it is a frog and a stork or a goat and a giant, for as long as the power balance remains the same.

\subsection{Context}

While analysing the semantic level phenomena, it became evident that the participants rely on different types of context while trying to understand single words, phrases or even whole passages. Contextual 
knowledge can be described as the process of understanding a word or a passage because of the preceding or following parts, as predictability of the meaning of certain words or passages (see Laszlo \& Federmeier 2009: 326-327).

Brock and Nation (2014: 114) use the term immediate context to indicate "that certain forms of contextual information can have a nearimmediate effect on word identification" and Laszlo and Federmeier (2009: 328) talk about the morpho-syntactic and phonological features of upcoming words that can be pre-activated by sentence contexts. In this study, the participants used various strategies for applying context in their inference process. Several examples will be presented, that show how participants activate the so-called immediate context by deducting the meaning of a word from the context or generating context knowledge with the help of familiar words and the sentence context by deducing the meaning of a sentence from another sentence.

In example (18), Julia tries to find the meaning of a single word she does not know. She recognizes a couple of words and tries to find the meaning with the help of the other words she already translated.

(18) J [hun/ger]

(10s) (ähm) (...) nach einer Woche (9s) noch... még az egész világot a játék das ganze (..) Licht auf das Spiel (..) vielleicht ist hódított (.) so ein... werfen... ein anderes Licht auf das Spiel werfen (..)

[(10sec) (um) (...) after a week (9sec) still... the game the whole world all the (..) light on the game (..) maybe conquered means (.) like... throwing... another light on the game (..)]

The sentence Julia tries to translate in example (18) translates to English as 'the game Pokémon Go conquered the world within a week'. Julia thinks she understands everything except for hóditotta 'conquered' and tries to deduce this unknown word on the basis of the other words. She falsely translates the word világ 'world' as 'light' and completes the phrase with the assumed meaning of 'light' with the verb that makes up the phrase Licht werfen 'to throw light'. She explains her translation as follows: 
(19) I [hun/ger]

I: Wie hast du dir den Schluss hergeleitet? Mit „ein anderes Licht auf die Welt werfen"?

J: Ich habe mir die einzelnen Wörter angeschaut, die ich weiß und habe mir dann gedacht, wie sich's im Deutschen gut anhört und habe dann auf das Unbekannte geschlossen.

[I: How did you deduce the end? This "throwing another light on the world"?

J: I looked at the words I know and thought about what would sound good in German, and tried to draw conclusions for words I didn't know.]

In example (19) Julia describes that she first looked at the individual words. After that she tried to figure out what sounds good in German, to fill the gaps in Hungarian. With the help of the familiar words, she created a certain context. In this created context she was looking for appropriate words in her stronger language, German, to complete the sentence. The source of the translation problem is the word világ, as it has two meanings: world and light, and choosing the wrong meaning activates a wrong context. Thus, drawing a conclusion based on the familiar context is albeit a fairly common method for translating, only successful if the other context is correctly interpreted.

Some participants also work with the sentence-external context. They deduce the meaning of one sentence from the meaning of another sentence, because they often have some idea of the meaning of one sentence but are not entirely sure of it. Only the meaning of the following sentence confirms their respective theories.

(20) C [hun/ger]

Békákra vadászott... das kenn ich nicht, aber (.) irgendetwas... es ist irgendetwas mit einem Frosch. Ebböl élt... er hat davon gelebt, also wahrscheinlich hat er Frösche gefangen. (..)

[He hunted frogs... I don't know the meaning, but (.) something... there's something about a frog. That was what he survived on... He survived on that, so probably he caught frogs (..)] 
As example (20) shows, Caro is not sure about the meaning of the first phrase, Békákra vadászott 'he hunted frogs'. After being able to translate the following sentence, Ebböl élt as 'he survived on that', she knows the first sentence must refer to the stork catching frogs. Knowledge of the world, in that case being that storks hunt frogs, is probably decisive in that respect. In example (21), Julia interestingly uses the same method, only leading to different results.

(21) Békákra vadászott... (.) (ähm) (..) er wurde gejagt... der Frosch, oder er jagte. (...)Das kann ich jetzt aufgrund von (.) dem (..) von dem Ende nicht ableiten... von der Endung... ra... békákra... (...) es ist Plural (.) und irgendeine Endung. Ebböl élt... Ah ok, aufgrund vom nächsten Satz... deswegen starben sie (.) glaub ich (.) also (.) kann ich dann sagen, dass sie gejagt wurden, denk ich (...) also békákra ist die Frösche wurden gejagt (...)

[He hunted frogs.... (.) (um) (..) He was hunted... the frog or he hunted. (...)I cannot (.) on the basis of (..) I cannot deduce from the end... from the ending... for... for frogs... (...) it is plural (.) and some suffix. That was what he survived on... Ah ok, on the basis of the next sentence... this is why they died (.) I think (.) well (.) I can then say that they were hunted, I think (...) so of frogs means the frogs were hunted (...)]

In example (21) Julia cannot translate the first sentence, Békákra vadászott 'he hunted frogs'. She translates the next sentence incorrectly too, as "this is why they died". Nevertheless, based on that, she draws the right conclusion concerning the previous sentence "the frogs were hunted". Her initial incorrect translation gets corrected, as she translates the following sentence incorrectly but fitting to the general context.

In general, the examples above show that the participants can deduce sentences from the context and think on a larger scale. They do not only resort to understanding single words, but can find the meaning with the help of the immediate or wider, sentence context. 


\section{Discussion and conclusion}

The goal of this study was to investigate which language comprehension strategies are used by German-speakers with receptive skills in Hungarian, while reading two short texts in Hungarian. For this paper, I limited the analyses to the following categories: learners' strategies and the socalled "lower procession levels" according to Lutjeharms (2002), such as syntactic levels or word recognition. A total of eight German-speaking persons with receptive skills in Hungarian took part in the think-aloud study carried out in 2017/18.

The outcomes of this study show that receptive bilinguals do understand written texts and do use various strategies. The right articulation of what is written/heard/read is a prerequisite for the ability of accessing the right words. The introspection by the participants showed that many words in the text were familiar to the participants, even if they had never been connected to a meaning. This phenomenon is called "lack of contrast". For the participants, working on the basis of contextual knowledge and knowledge of the world is very rewarding. Ultimately the receptive bilinguals also do creative guesswork, wanting to work on general content rather than on translating word-by-word. The used strategies show the strong willingness to understand the global storyline and not stopping the translation at unknown passages. Indeed, most of the participants could generate content and access the semantic level. Thus, these results prove the high linguistic potential of receptive bilinguals that goes beyond minimal linguistic knowledge. This should be taken into consideration when it comes to language learning or language acquisition.

However, this research is not without limitations. Most of the participants are used to only listening to Hungarian and thus were not familiarized with reading in Hungarian. A listening task would have probably led to different results. Also, the fact that the participants were not allowed to ask for the meaning of the vocabulary or use any other help prevented the potentially very productive use of problem-solving 
strategies, which are now understandably underrepresented and therefore not discussed in this paper. Due to the small sample size, this article could only present a small number of results concerning receptive bilingualism and reading, but it will hopefully stimulate further research about language acquisition and language learning, especially in the context of migration and in border regions.

\section{Acknowledgements}

Special thanks to LV-series editor Hanna-Ilona Härmavaara for helping to improve my article. Thanks to my friends Magdalena Eybl-Vyhnanek, Kirsten Mericka and Petra Reiter for their inputs.

\section{References}

Az utolsó béka. Afrikai népmese. - Nők lapja 2016. Július 27 (30), 48.

Bachtin, Michail 2015. Die Ästhetik des Wortes. - Andreas Langenohl, Ralph Poole, Manfred Weinberg (eds.). Transkulturalität. Klassische Texte. Bielefeld: transcript Verlag, 199-212.

Brock, Jon, Kate Nation 2014. The Hardest Butter to Button: Immediate Context Effects in Spoken Word Identification. - The Quarterly Journal of Experimental Psychology 67 (1), 114-123. https://doi.org/10.1080/17470218.20 13.791331

Campbell, Lyle, Martha C. Muntzel 1989. The structural consequences of language death. - Nancy C. Dorian (ed.). Investigating Obsolescence. Studies in Language Contraction and Death. Studies in the Social and Cultural Foundations of Language 7. Cambridge: Cambridge University Press, 181-196. https://doi.org/10.1017/CBO9780511620997.016

CEFR = Common European Framework of Reference for Languages: Learning, Teaching, Assessment. Council of Europe / Conseil de l'Europe. Cambridge: Cambridge University Press, 2001.

Dengscherz, Sabine 2005. Spiegelübersetzung als Lernhilfe? Äquivalenz und Kontrast ungarischer Lokalkasus und der deutschen Präpositionen an, auf, aus, bei, in, von, zu. Eine empirische Untersuchung zum Einfluss der Muttersprache bei ungarischen Deutschlernenden und deutschsprachigen Ungarischlernenden. PhD thesis. Wien.

Deutsche Literatur: Dialogizität. http://www.litde.com/verfahren-der-textanalyse/ dialogizitt-intertextualitt-gedchtnis/dialogizitt.php (31.7.2017). 
LANGUAGE COMPREHENSION STRATEGIES OF GERMAN LANGUAGE SPEAKERS

Duden 2009. Die Grammatik: Unentbehrlich für richtiges Deutsch. Bd. 4. 8th revised edition.

Forgács, Tamás 2001. Ungarische Grammatik. Wien: Ed. Praesens.

Friederici, Angela D. 1987. Kognitive Strukturen des Sprachverstehens. Lehrund Forschungstexte Psychologie 23. Berlin: Springer-Verlag. https://doi. org/10.1007/978-3-642-72657-6

Früh, Werner 2015. Inhaltsanalyse. Theorie und Praxis. 8th revised edition. Konstanz: UVK Verlagsgesellschaft.

Gold, Andreas 2007. Lesen kann man lernen. Lesestrategien für das 5. und 6. Schuljahr. 2nd edition. Göttingen: Vandenhoeck \& Ruprecht.

Gooskens, Charlotte, Vincent J. van Heuven, Jelena Golubović, Anja Schüppert, Femke Swarte, Stefanie Voigt 2018. Mutual intelligibility between closely related languages in Europe. - International Journal of Multilingualism 15 (2), 169-193. https://doi.org/10.1080/14790718.2017.1350185

Heine, Lena 2014. Introspektion. - Jutta Settinieri, Sevilen Demirkaya, Alexis Feldmeier, Nazan Gültekin-Karakoc, Claudia Riemer (eds.). Empirische Forschungsmethoden für Deutsch als Fremd- und Zweitsprache. Eine Einführung. Paderborn: Schöningh, 123-135.

Hetzer, Armin 2009. Ungarisch und Deutsch in ihren wechselseitigen Beziehungen. - Christel Stolz (ed.). Unsere sprachlichen Nachbarn in Europa: die Kontaktbeziehungen zwischen Deutsch und seinen Grenznachbarn. Bochum: Brockmeyer, 115-132.

Heuven, Vincent J. van, Charlotte Gooskens, Renée van Bezooijen 2015. Introducing MICRELA: Predicting Mutual Intelligibility between Closely Related Languages in Europe. - Studies in Psycholinguistics 19. Tinta Könyvkiadó, 127-145.

Hoey, Michael 2005. Lexical Priming: A New Theory of Words and Language. London: Routledge.

Jessner, Ulrike 2006. Linguistic Awareness in Multilinguals: English as a Third Language. Edinburgh: Edinburgh University Press. https://doi.org/10.3366/ edinburgh/9780748619139.001.0001

Kintsch, Walter 1998. Comprehension: A Paradigm for Cognition. Cambridge: Cambridge University Press.

Kuckartz, Udo 2016. Qualitative Inhaltsanalyse. Methoden, Praxis, Computerunterstützung. 3rd revised edition. Weinheim and Basel: Beltz Juventu.

Laszlo, Sarah, Kara Federmeier 2009. A beautiful day in the neighborhood: An event-related potential study of lexical relationships and prediction in 
context. - Journal of Memory and Language 61 (3), 326-338. https://doi. org/10.1016/j.jml.2009.06.004

Lippert, Susanne 2010. Sprachumstellung in bilingualen Familien: Zur Dynamik sprachlicher Assimilation bei italienisch-deutschen Familien in Italien. Mehrsprachigkeit 28. Münster \& Regensburg: Waxmann.

Lutjeharms, Madeline 2002. Lesestrategien und Interkomprehension in Sprachfamilien. - Gerhard Kischel (ed.). Eurocom: Mehrsprachiges Europa durch Interkomprehension in Sprachfamilien; Tagungsband des internationalen Fachkongresses im Europäischen Jahr der Sprachen 2001. Hagen: Fernuniversität, 124-140.

Mayring, Philipp, Eva Brunner 2013. Qualitative Inhaltsanalyse. - Barbara Friebertshäuser, Antje Langer, Annedore Prengel (eds.). Handbuch Qualitative Forschungsmethoden in der Erziehungswissenschaft. In cooperation with Heike Boler and Sophia Richter. 4th revised edition. Weinheim and Basel: Beltz Juventu, 232-333.

Muikku-Werner, Pirkko, Jarmo Harri Jantunen 2020. Understanding Estonian phraseological units on the basis of Finnish: Contributing and misleading factors. - Lähivõrdlusi. Lähivertailuja 30, 155-186. https://doi. org/10.5128/LV30.04

O'Malley, J. Michael, Anna Uhl Chamot 1995. Learning Strategies in Second Language Acquisition. 4th edition. Cambridge: Cambridge University Press.

Pokémon Go. - Nők lapja 2016. Július 27 (30), 8.

Rehbein, Jochen, Jan D. ten Thije, Anna Verschik 2012. Lingua receptiva (LaRa) - remarks on the quintessence of receptive multilingualism. International Journal of Bilingualism 16 (3), 248-264. https://doi.org/ $10.1177 / 1367006911426466$

Riemer, Claudia 2014. Forschungsmethodologie Deutsch als Fremd- und Zweitsprache. - Jutta Settinieri, Sevilen Demirkaya, Alexis Feldmeier, Nazan Gültekin-Karakoc, Claudia Riemer (eds.). Empirische Forschungsmethoden für Deutsch als Fremd- und Zweitsprache. Eine Einführung. Paderborn: Schöningh, 15-31.

Romaine, Suzanne 1989. Bilingualism. Oxford: Blackwell.

Safont Jordá, Maria Pilar 2005. Third Language Learners: Pragmatic Production and Awareness. Second Language Acquisition 12. Clevedon \& Buffalo \& Toronto: Multilingual Matters LTD. https://doi.org/ $10.21832 / 9781853598043$

Scherfer, Peter 2002. Was ist und wie erlernt man Interkomprehension? - Gerhard Kischel (ed.). Eurocom: Mehrsprachiges Europa durch Interkomprehen- 
sion in Sprachfamilien; Tagungsband des internationalen Fachkongresses im Europäischen Jahr der Sprachen 2001. Hagen: Fernuniversität, 87-101. Sherkina-Lieber, Marina 2020. A classification of receptive bilinguals: Why we need to distinguish them, and what they have in common. - Linguistic Approaches to Bilingualism 10 (3), 412-440. https://doi.org/10.1075/ lab.17080.she

Sherkina-Lieber, Marina, Ana T. Pérez-Leroux, Alana Johns 2011. Grammar without speech production: The case of Labrador Inuttitut heritage receptive bilinguals. - Bilingualism: Language and Cognition 14 (3), 301-317. https://doi.org/10.1017/S1366728910000210

Vetter, Eva 2011. Exploiting receptive multilingualism in institutional language learning: The case of Italian in the Austrian secondary school system. - International Journal of Bilingualism 16 (3), 348-365. https://doi. org/10.1177/1367006911426385 


\title{
Saksakeelsete ungari keele retseptiivse oskusega keelekasutajate mõistmisstrateegiad
}

\author{
ISABEL ZINS
}

Artiklis käsitletakse saksa keelt esimese keelena kõnelevate retseptiivse ungari keele oskusega keelekasutajate mõistmisstrateegiaid ungari keeles. Uurimus soovib anda põgusa ülevaate retseptiivsest mitmekeelsusest olukorras, kus mõistmisprotsessis osalevad keeled ei ole sugulaskeeled.

Uurimuses osalejad omavad teatud teadmisi ungari keelest ja on puutunud ungari keelega sageli kokku, aga nende aktiivne ungari keele oskus on vähene. Uuringus vaadeldi, kuidas ja milliseid strateegiaid uurimuses osalejad kasutavad, et mõista kaht lühikest ungarikeelset teksti. Mõistmisprotsessi ja -strateegiate väljaselgitamiseks kasutati teksti lugemise ajal introspektiivset meetodit, valjusti mõtlemist (thinking aloud).

Analüüsitud materjalis kasutatud mõistmisstrateegiad viitavad rohkele kontekstipõhisusele ja üldteadmiste kasutamisele. Teksti mõttest ja sõnade tähendusest saadakse aru juba tuttavatele sõnadele tuginedes; tundmatute elementide tähendus leitakse arvamise teel, jäetakse välja või asendatakse millegi sarnasega. Sõnade äratundmisele aitab kaasa nende häälduse täpne mäletamine. Tulemuste tõlgendamisel mängib olulist rolli ka nn "kontrasti puudumine": kuigi osalejatele kõlavad teatud sõnad tuttavalt, ei osata nendele konkreetsetele sõnadele omistada ühtegi tähendust.

Võtmesõnad: retseptiivne mitmekeelsus; mõistmisstrateegiad, kirjalikud tekstid; introspektsioon; valjusti mõtlemine; ungari keel; saksa keel

Isabel Zins

Brigittenauer Lände 160-162/3/12

1200 Vienna, Austria

isabel.zins@gmx.at 